\title{
“GOOD ADMINISTRATIVE LANGUAGE" FROM THE PERSPECTIVE OF PUBLIC ADMINISTRATORS WITH L2 BACKGROUNDS
}

\author{
Jyrki Kalliokoski \\ University of Helsinki
}

\begin{abstract}
Clarity, pertinence and comprehensibility are stated in the legislation as guiding principles of the language of Finnish public administration. This article presents professional administrators' views about these ideals of administrative language. The issue of good linguistic practices in public administration is discussed from the perspective of professionals who have learnt Finnish as adults. The data come from interviews with professionals (Finnish as L2) and their superiors (Finnish as L1) working in public administration. The article addresses the interviewees' conceptions of the relevance of clarity, pertinence and comprehensibility in their daily work and their language socialization into the workplace community, the audience design of administrative communication and their agency as users of Finnish administrative language. The analysis shows that the multilingual professionals are confident about their language skills and aware of the varieties of Finnish administrative language and the restrictions in their use. The native speaker superiors refer to the models offered by the more formal bureaucratic genres as an explanation for the linguistic "complexity" that they have occasionally perceived in texts produced by administrators with L2 backgrounds. Instead of adhering to the norms of (formal) standard language, the interviewed superiors promote efficiency as a quality of good administrative language.
\end{abstract}

Keywords: language of administration, language ideologies, second language use, language socialization, language planning

DOI: https://doi.org/10.12697/jeful.2017.8.1.04

\section{Introduction}

The principle according to which the citizens should be able to understand administrative language - instructions, decisions, laws and other information produced in the public administration - can be considered as an essential part of a democratic state. This principle is also stated in the Finnish administrative legislation. The language use of the Finnish public administration has been under continuous planning 
and development, especially since the last decades of the 20th century. The action plan ("Hyvän virkakielen toimenpideohjelma", 2014) for enhancing good practices in the language use of the public administration is the latest joint effort by the Ministry of Education and Culture and the Centre for languages in Finland. This document emphasizes clarity, pertinence and comprehensibility as guiding principles in the language use of public administrators. Accordingly, the three adjectives clear, pertinent and comprehensible ${ }^{1}$ tend to surface repeatedly in the discourse about bureaucratic language and language practices in public administration.

How do the professional administrators themselves see these ideals? The action plan includes some short citations which represent voices of professionals working in public administration. There have been some studies touching this issue (e.g. Tiililä 2009) but the focus of the research has predominantly been on texts produced in public administration and, to a much lesser extent, on interaction between professional administrators and citizens as their clients. Furthermore, the possible implications of the increasing diversity of client profiles of public administration during the recent years is still unexplored. In addition to the plethora of different administrative documents and other means of communication, the clientele of the Finnish public administration nowadays consists of people with more and more varying linguistic backgrounds. The professionals who are responsible of crafting administrative decisions or advising their clients orally or in writing, have to take into account the fact that the "public" of the public administration is not as homogenous as in the 20th century Finland and does not consist of individuals with the same linguistic and educational background. The recommendations concerning good linguistic practices in public administration have thus become more relevant than before.

Traditionally, Finnish professional administrators have been assumed to share with their clients a common linguistic background and a monolingual primary and secondary education in Finnish (or Swedish). Accordingly, their linguistic choices are judged in this monolingual and -cultural context. Since the beginning of the new millennium, not only the clientele of public administration, but also the picture of a linguistically and culturally homogenous Finnish public administration has become more diverse. At present, there are more and more professionals

1 The Finnish original uses the adjectives 'selkeä', 'asiallinen' and 'ymmärrettävä'. 
with different linguistic, cultural and educational backgrounds working in the Finnish public administration.

In this article, I will explore the issue of good linguistic practices in public administration from the perspective of professional administrators who have learnt Finnish as an additional language during or after their academic education in Finland. I will also address the notions of the agency and ownership of a language in the context of language use in administration. The study presented in this article is a part of a larger project on language ideologies among the multilingual professionals working in public administration in Finland. The data come from interviews with 11 professionals (Finnish as L2) and their 3 superiors (Finnish as L1) working at both national and more local (city) level.

\section{2. "Clear", "pertinent" and "comprehensible"}

The idea of clear, pertinent and comprehensible language has a long history in language planning in Finland and in European (language) ideologies in general. Furthermore, most of the professional administrators (like all Finnish citizens) have been taught to appreciate pertinence, clarity and comprehensibility in language use during their educational career. Despite the efforts of the educational system and language planning authorities, there appears to exist a nationwide consensus about the fact that language use in public administration is in need of constant developing and that recommendations about good linguistic practices have to be promoted ("Hyvän virkakielen toimenpideohjelma", 2014). In these discussions, the existence of a homogenous entity called "language of administration" is taken for granted. This monolithic notion of value-neutral administrative language, shared by professional linguists and laymen alike, however, conceals the potential variation in the language of public administration (cf. Canagarajah 2013: 110). Fortunately, even though the recent action plan uses the concept "language of administration" ('virkakieli'), it acknowledges the existence of variation across genres - and thus implicitly challenges the idea of a monolithic "language of administration" ("Hyvän virkakielen toimintaohjelma", 2014). The variety of genres and linguistic practices in the administrative work is mentioned in the recommendations of the action plan and its examples.

The English abstract of the action plan explicitly states the link between "clear administrative language" and democracy: 
The basic idea in the working group's proposals is that clear administrative language is an essential element of any democratic society. The aim is to ensure that this legislative requirement is better met. [- - ] Clear language saves time and effort, improves efficiency and safeguards the legal protection of customers. ("Hyvän virkakielen toimenpideohjelma", 2014)

Clarity as an ideal for (public) language use has deep roots in the European thought. The representatives of the classicist poetics (Boileau, Pope, and their predecessor in the Antiquity, Horace) were champions for clarity in poetry and held clarity as an aesthetic ideal. Furthermore, the 17th century rationalist philosophers such as Francis Bacon and John Locke advocated for "purification" of language (Bauman and Briggs 2003, see also Thomas 1991). Especially Locke set pure and clear language as an ideal for science and for the language use of government and aristocracy, whereas ambiguous "poetic" elements in language and linguistic variation were associated with the common people and condemned as impure (Bauman and Briggs 2003: 59-64, 301). The puristic language ideology lives on in language planning and language policy (Bauman and Briggs 2003: 301-309). In Finland, linguistic purism is mostly connected with rejection of "foreign" influence (Rintala 1992, Mäntynen 2003, Nordlund 2004, Piippo 2012), in other words, influence of Swedish or nowadays English on Finnish language (as for purism regarding the influence of Finnish on FinlandSwedish, see Hällström-Reijonen 2012).

The argument for democracy which is mentioned in the recent action plan also has a history in the tradition of Finnish planning (Voutilainen 2016: 169-171). The democratic ideal can be traced back to language ideology of Romanticism, most notably to the work of Johann Gottfried Herder for whom linguistic variation and poetical language presented the original oral tradition, the voice of the people, das Volk (Bauman and Briggs 2003: 186-187). It is fascinating how the Rationalistic ideal of purified, clear language of the elite, and the Romantic ideals of promoting democracy and vernacular language varieties are simultaneously present in contemporary discourse on administrative language (cf. Mäntynen et al. 2012). Both of these aspects are manifest in the interview data of the multilingual professionals of administration and their superiors. It should be noted, however, that purism concerning "foreign", interlingual influence did not surface in the interviews at all, while the issues of clarity, appropriateness and comprehensibility are present throughout the data. 
Language ideologies and conceptions about good administrative language are shared by the community of practice formed by the professionals working in the Finnish public administration. Within the community of public administrators, conceptions and ideals about language use are passed from generation to generation as the novice members are being socialized into the linguistic practices of the community (cf. Wenger 1998 and also Roberts 2011). While a professional administrator with a Finnish as L2 background obviously enters Finnish administrative community from outside, one has to keep in mind that also those with Finnish as their L1 have to learn to become a member of the same community. Therefore it is not surprising that the same stereotypes and language ideologies concerning administrative language can be found in the interviews both with the multilingual administrative professionals and their superiors with Finnish as L1. In the following, I will show how these conceptions and practices are expressed in the interview data. Furthermore, I will present some alternative voices which actively challenge these ideals and claim co-ownership of the Finnish (administrative) language.

\section{Clarity, pertinence and comprehensibility in the daily work of professional administrators}

Most immigrants do not enter Finland carrying along "their variety" of Finnish but have to learn the new language in order to enter the working life. The interviewees in my data are academically educated professionals with migrant backgrounds who have acquired their language skills through hard work. Due to their individual (linguistic) biographies, they have gained access to different varieties of Finnish. The interviewees have layered identities (Kurhila 2001), which are activated in different interactional contexts in their work: they have identities as administrative professionals and colleagues, as consultants and advisers (to various organizations and individual citizens) and the identity of a non-native speaker of Finnish. These identities are activated in their daily work when encountering multiple audiences: colleagues in one's own unit and within the networks of public administration as a whole but also representatives of interest groups and individual citizens as clients.

The ideal administrative language is a recurring topic in the interview data. In the interviews, the administrative professionals who have learnt Finnish as adults reflect their own linguistic histories and their 
career in public administration, and assess their workplace community as an environment for language use. In the following example $\mathrm{John}^{2}$ (L2 speaker of Finnish) is talking about his own socialization into linguistic practices of his workplace community (Roberts 2011):

$\mathrm{J}(\mathrm{L} 2)$ : joo tästä keskusteltiin että et ku tänne tulin ni yritin tuottaa sellasta, (0.6) sellasia niinku hyvin yksinkertaisia selkeitä tekstejä sillä kielitajulla mikä mul oli sillon? mutta musta tuntuu että, (1.6) että tota, mun (0.6) kielitaito on, .hh (0.4) ikävä kyllä. (1.4) kehittynyt, niin, (.) hyvin voimakkaasti tohon niinkun virkamies, (1.0) kieleen suuntaan että? (0.6) jos katselen nykyisiä? tai tai nykyään kirjottamiani, lausuntoja ja kannanottoja, mm joissa siis tavallinen kansalainen ei edes ymmärtäisi mistä mä oon, kirjottamassa? ${ }^{3}$

[yeah, we discussed this that when I came here I tried to produce something, (0.6) something like very simple clear texts using the language skills I had then? but I feel that, (1.6) that well, my (06.) language skills have, ..hh (0.4) unfortunately developed, so, (.) very strongly like into the direction of the language of a civil, (1.0) servant that? (0.6) if I look at the present? or or the reports or comments that I have written nowadays, mm in which an ordinary citizen would not even understand what they are about.]

John first refers to the beginning of his career in his present workplace ( $k u$ tänne tulin) and describes his professional ambitions as follows: yritin tüottaa [- - ] hyvin yksinkertaisia selkeitä tekstejä. The rest of the excerpt expresses frustration about the transformation of his linguistic practices into officialese and the potential incomprehensibility of the texts he produces at present. The next example comes from the same interview. Here John explicates several features of a good administrative language:

J(L2): se ov vaa valtion tapa kirjottaa mut, kielellisesti tota niin? paljo selkeempää. (1.8) tekstiä olisi kaikille hyvä. (1.6) lyhyempiä lauseita, selkeitä, (1.8) [- - - ] voi olla asiantuntija joka kirjottaa? monimutkasia ja, (0.6) paljon asiaa sisältäviä tekstejä mutta, (0.6) saattaa olla et ratkaisu on niinku lyhyitä selkeitä, (0.6) hienosti rakennettuja, (0.4) lauseita jotka niinku tuovat sen asian selkeesti esille ja, (0.8) mutta, ei välttämättä monimutkaisesti,

2 The names of the interviewees are changed into pseudonyms in order to protect their anonymity.

3 See appendix for transcription symbols. 
[it's just the way one writes in the state [administration] but, linguistically well yes? a much clearer. (1.8) text would be good for everyone. (1.6) shorter clauses, clear, (1.8.) [ - - ] [one] can be an expert who writes? complex and, (0.6) texts with lots of content but, (0.6) it may be that the solution is like short clear, (0.6) well constructed, (0.4.) clauses which like present the idea clearly and, (0.8) but, not necessarily in a complicated manner, ]

John is here focusing on citizens' needs concerning administrative texts and using the claim for democracy to support his argumentation (selkeempää tekstiä. olis kaikille hyvä), discussed above (p. 3 above). A professional's view on the relationship between linguistic choices and the meaning which administrative texts are supposed to communicate to citizens is strongly present in John's talk in both examples above. Clarity of administrative language is one of the recurring themes in his formulations.

Stereotypical qualities of bureaucratic language include unnecessary (syntactic) complexity of administrative texts. The interviewees in the data refer to something which they label as a "heavy" construction ('raskas rakenne'). Also the term kapulakieli ('officialese') is explicitly mentioned in many interviews as a part of the daily linguistic routines in administrative work - and as something to be avoided. In the following example, Daria is explaining the interviewer about corrections made by colleagues and superiors in her texts.

D(L2): saattaa olla et mä käytän (0.4) paikotellen liian puhekielistä tyyliä, (0.4) sitä saatetaan korjata, hh ääm, (1.0) mut (0.2) se on tällästä hiontaa et joskus muutetaan kokonaisii rakenteita kevyemmiksi et,.hh oikeestaan mulla ei oo sitä. .hh ongelmaa et mä tekisin liian kevyttä rakenteita vaan mä teen aika raskaita. hh ja niitä. (0.2) .hh kevennetään? ei toisin päin? [it may be that I use (0.4) from time to time style which is too close to spoken language, (0.4) it can be corrected, .hh erm, (1.0) but (0.2) it really is like polishing that sometimes they change whole structures into more lighter ones that, .h hactually I don't have the problem that I would make too light constructions but I do make quite heavy ones. hh and they. (0.2) are made lighter? not the other way round?]

References to unnecessarily heavy constructions can be found in the superiors' interviews, as well. Especially one of them is paying attention to complex syntactic structures used by the multilingual administrative professionals working in her unit. According to her interpretation, heavy constructions can be traced back to intertextual 
models provided by previous administrative texts. The implication here seems to be that using an L2 as a working language can explain the "overuse" of complex structures. In the following example, Saara (L1 speaker of Finnish) is using the phrase liian monimutkasia lauserakenteita ('too complex syntactic structures') when referring to problems in clarity of language use and to the model provided by previous administrative texts. Furthermore, she implies that linguistic features of decision documents should not be transferred to other genres, such as e-mail communication.

S(L1): et? (.)kym mä niin ku X:n kohalla ehkä oon joskus huomaavinani just sitä et hän käyttää liian monimutkasii lauserakenteita koska se?.hh varmaan se muistikuva on niist teksteistä joita hän on lukenut, että se on? kirjotettu sellaisella? (.) lauserakenteellah? nin mm ni missä tavallaan päätöksentekoon? teksti on just sitä et yyhd-? yhdellä? (.) lauseella yritetään räjäyttää koko pankki, (0.8) et sitte ehkä? että jos sitä on ollu siirtymässä sen tyyppistä ni? sähköposteihi ni sit sit mä oon just sielä tehny sitä et? et tää ois parempi kirjottaa näi lyhyemmin ja? .hh asia selkeemmin vielä esille?

[that? (.) yeah speaking of X perhaps I have seemed to notice that just that he uses too complex syntactic structures because it? .h probably this recollection comes from those texts which he has read, that it has been? written using such a? (.) syntactic construction? that mm which for decision making? the text is just like [by using] on-? one? (.) clause one tries to capture everything, (0.8) that then perhaps? that if there had been that type [of writing]? moving into e-mails well then I have in these cases done so that? that it would be better to write this like this shorter and? .hh [to formulate] the idea in a clearer way?]

In addition to the three adjectives clear, pertinent and comprehensible and the democratic ideal stated in the law, the action plan takes up the notion of efficiency in language use ("Clear language saves time and effort, improves efficiency and safeguards the legal protection of customers", see the citation above, p. 2), as well. The issue of efficiency is mentioned in the interview data, as well. The following excerpt comes from an interview with a superior (Finnish as L1) who characterizes the language use of the multilingual professionals as follows:

K(L1): mikä on riittävä kielitaito(.) jos niinku ajatellaan niinku tätä meidän työtä ni riittävä kielitaito on sitä että asiakkaat ovat tyytyväisiä saamaansa (.)palveluun [- - - että jos mä rupeen niinku miettii että onko ne ihan oikeesti että onko se oikeekielistä se puhe tai onko se oikein kirjoitettua ni eihän se ole. 
[what is enough when it comes to language skills (.) when thinking about our work the sufficient language skills mean that the clients are satisfied (.) with the service they get [- - -] that well (.) if I start to think that are they really (.) that is the speech correct [language] or is it written correctly (.) well it is not.]

In the excerpt above Kirsi is advocating for efficiency, even at the cost of paying attention to the norms of Standard Finnish. Efficiency here seems to imply a "customer" and a "service" approach to administrative communication. To some extent, Kirsi's words can be interpreted as talk about appropriateness and pertinent linguistic practices in administration.

\section{Administrative language and citizens as audience}

Defining the potential audience is an essential part of producing texts in public administration. Some texts are designed for colleagues working in others sectors of public administration and others are meant to address a wider public, citizens or NGOs waiting for a decision or wanting information. When developing better practices in administrative language, the emphasis has been on the needs of citizens as audience. Clarity and comprehensibility from the citizens' perspective is discussed by the interviewees in my data, as well. In the following excerpt, Ella gives an example of problems of clarity and comprehensibility from the point of view of an unemployed individual:

E(L2): esimerkiksi kun asiakas semmonen hyvä esimerkki? .hh kun asiakas on öö, eka kerta työnhakijana. ä työkkärissä, [ - - - ja on aina sellanen lause,@ei o esteettä@(1.0).hh ö@työtömys turvan maksamiseen@,ja kun ihminen, (.)näkee, että se on?(0.8) negatiivinen lause, sitte hänelle on hh hiukset pystyssä ja hän luulee että, täälä on jotain. sitten hän tulee kysymään. .hh ja ma selitän hänelle että, s- sis, ö m älä pelkää? kaikki on kunnossa? se on vain sellanen lause.

[for example when a customer a good example? .h h when a customer is erm, for the first time as seeking work erm at the employment office, [- - ] and there is always a sentencelike, @there isno obstacle@ (1.0).hherm@for paying the unemployment benefit@, and whena person, (.) sees [this]she thinks that, here is something. then she comes to ask. .h and I explain to her that, we-well, erm don't be afraid? everything is alright? it's just that kind of clause.] 
Earlier in the interview Ella has emphasized the fact that if a person with Finnish as L1 does not understand texts produced by public administration, how can a person with an L2 background be expected to understand it. Throughout the data the interviewees are communicating their concern about the quality of administrative texts and the citizens' possibilities to understand them, and expressing empathy towards individuals who are trying to cope with the problems caused by opaque expressions of bureaucratic discourse. These worries are part of the interviewees' daily work, as many of them are engaged in issues of equality, employment services and advising clients both with and without an immigrant background.

Different texts have different audiences, and when designing administrative documents, one has to take into account these differences. In the example below, Daria is sketching - somewhat sarcastically - her recommendations for appropriate textual practices depending on potential audience segments for texts which are being produced within municipal administration. Among these 'good' practices she also mentions the use of models provided by previous texts as a solution for audience design.

D(L2): suoraan sanoen sehän riippu aivan, (0.6) hirvittävästi siitä kenelle tämä teksti on osoitettu .hh (0.2) elikkä (0.4) kaupungin hallinnolle (0.4) ne on tietyt rakenteet jotka ovat hyvinkin jäykät eli $(0.4) \mathrm{m}$ - paras vaihtoehto on kopioida vanhemmasta tekstistä? .hh £niitä et sit se£ ainaki kelpaa (0.6) kelpaa siellä puolella m- taas, .hh ömh. (0.2) asiantuntijoille on tosi tarkka. (0.8) tekstiä? (0.4) siis (0.2) tarkasti tuotetut määritelmät ja rajaukset koska (0.2) ne on sit ohje toimenpanoon ja jos la- (.) sanoo liian laveasti niin sit .hh jää epäselväks kuka tekee kuinka paljon tekee mitä tekee mi- (0.2) mille kohderyhmälle, .hh (0.2) pitää olla hyvin tarkat lauseet? (0.6) aahm, (1.0) .hh kuntalaisille hh (0.8) aina riippu kontekstista mutta (0.2) selkosuo- $(0.2)$ eh suomalaista kunnioitusta viestivää?

[strictly speaking it depends awfully, (06) much on to whom the text is addressed .hh (0.2) that is (0.4) to the city administration (0.4) there are these certain structures which are very stiff indeed so that (0.4) $m$ - the best option is to copy from an older text?. hh fthose so that isf will certainly do (0.6) over there $m$ - whereas, .hh erm. (0.2) to experts it has to be [a] really precise (0.8.) text? (0.4) well (0.2) strictly formulated definitions and limitations because (0.2) they will go to implementation and if one (.) formulates too widely well then .hh it remains unclear who does how much and what to whi-(0.2) which target group, .hh (0.2) the clauses must be very strict? (0.6.) erm, (1.0) .hh to the inhabitants in the municipality hh (0.8) always depends on the context but (0.2) clear Finn- (0.2) erm communicating Finnish respect?] 


\section{Agency and ownership of the Finnish administrative language}

Using language for crafting documents and communicating with individual citizens and various interest groups are the essential everyday activities of professionals working in public administration. The previous examples from the interview data show that the administrative professionals with a multilingual background have learnt the Finnish administrative language and its linguistic practices as a part the socialization process into their work when becoming members of their professional community. Using language and knowing the linguistic practices of Finnish public administration is the core of their professionality. They feel confident when using Finnish at work but they are also aware of their limitations in the use of different varieties of the Finnish language. The discursively produced agency as language users (Miller 2014:142-144) of these professionals is manifest throughout the interview data. Furthermore, even if they have learnt Finnish as adults, they have gained ownership of the Finnish language, at least the ownership of Finnish administrative language. Whether the workplace community, the professional community or the Finnish society at large will allow these new members full rights as users - and owners of the Finnish language, remains to be seen. The superiors in my data approached the topic of language skills and professionality mostly in a sympathetic manner. They often considered the linguistic backgrounds of their subordinates less relevant than their professional skills or the ability to master everyday routines such as the use of administrative databases and IT-systems. Below, Saara (superior, L1) is explicating this ranking of different skills that are needed in administrative work:

S(L1): niin tavallaan mä nään, et? (.) siin on tapahtunu ainaki sellanen positiivinen keikaus siihen et täs itseasiassa ni, .hh sitä, (.) ää kieltä tärkeempi asia on sen prosessin hallinta et miten se? menee päätöksentekoon, .hh ja sittes se mitä sen, .hh kielen hh kanssa tehdään, ni se tehdään itseasiassa ihan samat asiat ku mitä tehdään jonkun toisen erityissuunnittelijan? kohdalla.

[In a way I see, that? (.) there has been at least such positive change that in fact well, .hh (.) erm that controlling the process is more important than mastering the language that how it? proceeds to decision making .hh and then what one does with the, hh language, well one has to do just the same things as with any other special planning officer?] 
Saara is here talking about language requirements after passing a certain proficiency level in the use of Finnish. According to her, when a person knows Finnish well enough, linguistic or cultural background becomes insignificant in comparison to the professional qualities of the person. However, occasionally there are also more critical or worried voices to be heard in the interviews. In these comments, the superiors see themselves as mentors or guardians of their subordinates. The multilingual professionals who have learnt Finnish as adults are treated like novices: the implication is that a person under guardianship is not fully in possession of a language.

$\mathrm{S}(\mathrm{L} 1)$ : esimerkiks jos mä ajattelen että? että X:n tekemää tekstiä ni kyl mä ehkä?

.hhh sitä jotenkin niiku automaattisemmin katson sillä sillmällä että onko täällä sellaisia? .hh lauserakenteita esimerkiks että? .hh että niistä jää vähän hassu olo.

[- - - e- eli että? (.) kai se mun ajatus on että joku voi sit tulkita että hän on tyhmempi kuin? (0.6) joku toinen joka kirjottaa suomea täydellisesti tai sen lukijan toivomalla tavalla.

[if I think for instance that? that a text made by $X$ well yes I probably? .hh like somehow more automatically pay attention to things like are there such? .h syntactic constructions for instance that? .hh that would leave you with a funny feeling (.) [- - -] that is (.)perhaps I might be thinking that someone could then interpret that he is more stupid? (0.6.) than someone else who writes perfect Finnish or in the way which is expected by the reader.]

In the example above, Saara is talking about texts written by X, one of the members in her team. She takes up the topic of syntactic constructions in X's texts and reflects on her own reactions as a reader and speculates about possible interpretations of potential readers of X's texts. According to Saara's own interpretation, her willingness to control the language use of $\mathrm{X}$ is motivated by her effort to protect this person or to prevent others from making wrong conclusions about X's professional abilities (kai se mun ajatus on että joku voi sit tulkita että hän on tyhmempi kuin?(0.6) joku toinen.)

The interviewees with an L2 background reported that they could get support in editing texts and in other linguistic matters from their peers, both from those who have Finnish as L1 and from other colleagues who have learnt Finnish as adults. In the daily routines, however, one often has to rely on one's own (language) skills. All the interviewees seemed rather confident with their use of administrative Finnish (and 
their proficiency in Standard Finnish in general). This confidence is often combined with the sense of familiarity of administrative genres and their respective registers. In the following example, Daria gives a concise history of herself as a user of Finnish administrative language:

$\mathrm{D}(\mathrm{L} 2)$ : aluksi kun vielä ei ollut kokemusta siitä et minkälaista mun teksti on niin sitä tarkistuttiin enemmän mutta hh $(0.8)$ sen verran sen verran on (0.2) ollaan opittu että että tälläisessä (.) päivittäisessä kanssakäymisessä mä en enää tarkistuta mitään että .hh koko organisaatio on oppinut sitten lukemaan (0.2) pikkusen (0.2) erilaista suomee?

[at first when I did not have any experience of how my text is [like] so [I] had it checked more [often]but .hh (0.8) I have learned that much (0.2) that that in the (.) daily interaction I don't have anything checked so that .hh the whole organization has then learnt to read (0.2) a bit (0.2) different kind of Finnish?]

Daria's account of her present profile as a writer of administrative texts presents us a picture of a confident, almost defiant, professional language user who wants to enrich the linguistic varieties of her workplace community with her own contributions and is thus capable of challenging the native speakers' ownership of the Finnish language (cf. Canagarajah 2013). Daria's expression koko organisaatio on oppinut sitten lukemaan pikkusen erilaista suomee 'the whole organization has then learnt to read a bit different kind of Finnish' can be interpreted as an effort to legitimize her linguistic choices, her own variety as part of the Finnish (administrative) language. Confidence in one's own linguistic resources need not of course only imply defiance or challenging but confidence may arise from a sense of trust from the other members of the workplace community:

$\mathrm{J}(\mathrm{L} 2)$ : kielitaitoa tarkempi on, sen itseluottamuksen kehittäminen, (1.4) mun osalta? (0.6) .hh tällä hetkellä tiedän et vaikka kirjoitan tekstin, se sisältää virheitä. mut mul on sev verran itseluottamusta, (0.8) et? (0.4) hei? mun tekstiä luotetaan?

[more important than language skills is, developing self-confidence, (1.4) from my part? (0.6).hh at the moment I know that even if I write a text, it contains mistakes. but I've got that much self-confidence, (0.8) that? (0.4) c'mon? they trust my text?] 


\section{Concluding remarks}

The work of professional public administrators is done by using language, in writing and speech; their work consists of essentially linguistic activities. A person working in public administration needs to have a variety of linguistic resources in his or her possession. In the interview data, the administrators with an L2 background present themselves as professionals who know the linguistic practices needed at their work: they are aware of the varieties that are used in the Finnish administrative genres and the restrictions of their use, but they are often less confident when encountering other (e.g. dialectal) varieties of Finnish. In their talk, one can recognize the shared working culture and the language ideologies of communities of practice in ministries and offices of municipal administration.

The linguistic biographies of the professional administrators with L2 backgrounds show that achieving the linguistic competences needed for administrative work in the Finnish society obviously takes time and effort, also for the highly-educated immigrants. The comments of the superiors (native speakers of Finnish) reveal that regardless of their other professional skills and competence, the administrators with L2 backgrounds occasionally have problems in fulfilling the ideals of good administrative language. According to their superiors, the administrators using Finnish as L2 are sometimes (consciously or not) resorting to models provided by previous administrative documents and aiming at too "complex" linguistic structures in their own texts, and thus putting clarity, pertinence and comprehensibility of communication at risk. Both the native speaker superiors' and the L2 speakers' comments in the interview data reflect the principle according to which modern administrative practices should rather be based on a service approach than on control and authority. When citizens are perceived as clients and the role of an administrator as an advisor, the communication has to be sensitive to genre and to situational features, such as the persona of the addressee of an e-mail message or the reader of an administrative document. For instance, complex syntactic structures are frequent in some legislative and bureaucratic documents, where their extensive use can be considered appropriate, while in some other genres and situations more straightforward syntax and informal style is needed and, respectively, complex structures are regarded as emblems of bureaucratic jargon. Mastering grammar, vocabulary and pronunciation, and recognizing features of different varieties and styles are not enough as such: 
one has to be linguistically and interactionally sensitive in order to put this knowledge into use. The academically educated administrative professionals in my data, who have learned their working language as adults, encounter the same challenges as any highly proficient language learners. A great part of these challenges, however, are faced by all novices entering any community of practice (Wenger 1998), regardless of their linguistic backgrounds. Socialization in the linguistic practices at work is especially challenging in workplace communities where several linguistic varieties, genres and complex means of mediation are employed throughout the working day both in communication among professionals and between professionals and laypeople with different educational, linguistic and cultural backgrounds.

The ownership of the relevant linguistic resources and the appropriate linguistic practices of the workplace community are evaluated and challenged by public administrators themselves, by their colleagues and partners in professional networks, and by clients and readers of the administrative documents. These processes become more visible due to the varying linguistic and cultural backgrounds of the professionals working in public administration. The interview data presented in this article suggest that along the increasing diversity of the linguistic, cultural and educational backgrounds of both the producers and the readers of administrative documents, the "classic" qualities of good administrative language - clarity, pertinence and comprehensibility will maintain their status also in the future, although their meaning in administrative communication is constantly renegotiated.

\author{
Address: \\ Jyrki Kalliokoski \\ Helsingin yliopisto \\ Suomen kielen, suomalais-ugrilaisten ja pohjoismaisten kielten \\ ja kirjallisuuksien laitos \\ PL 3, Fabianinkatu 33 \\ 00014 Helsingin yliopisto \\ Helsinki, Finland \\ E-mail: jyrki.kalliokoski@helsinki.fi
}




\section{References}

Bauman, Richard and Charles L. Briggs (2003) Voices of modernity. Language ideologies and the politics of inequality. Cambridge: Cambridge University Press.

Canagarajah, Suresh (2013) Translingual practice. Global Englishes and cosmopolitan relations. London: Routledge.

Hyvän virkakielen toimintaohjelma. Opetus- ja kulttuuriministeriön työryhmämuistioita ja selvityksiä 2014:2. [Report of the Working Group for Clear Administrative Language]. Available online at $<$ http://www.minedu.fi/OPM/Julkaisut/2014/ hyva_virkakieli.html?lang=fi $>$. Accessed on 19.12.2016.

af Hällström-Reijonen, Charlotta (2012) Finlandismer och språkvård från 1800-talet till i dag. (Nordica Helsingiensia 28.) Helsingfors: Finska, finskugriska och nordiska institutionen, Helsingfors universitet.

Kurhila, Salla (2001) “Asiantuntijuuden kerrostumista. Syntyperäiset ja ei-syntyperäiset suomenpuhujat virkailijoina ja asiakkaina.” In Johanna Ruusuvuori, Markku Haakana, and Liisa Raevaara, eds. Institutionaalinen vuorovaikutus, 178-195. Helsinki: Suomalaisen Kirjallisuuden Seura.

Miller, Elizabeth R. (2014) The language of adult immigrants. Agency in the making. Bristol: Mulilingual Matters.

Mäntynen, Anne (2003) Miten kielestä kerrotaan? Kielijuttujen retoriikkaa. Helsinki: Suomalaisen Kirjallisuuden Seura.

Mäntynen, Anne, Mia Halonen, Sari Pietikäinen, and Anna Solin (2012) "Kieli-ideologioiden teoriaa ja käytäntöä”. Virittäjä 116, 325-348.

Nordlud, Taru (2004) "Arat taimet ja ankarat puutarhurit. 1800-luvun lopun kielikeskustelun metaforat ja kieli-ideologiat.” In Katja Huumo, Lea Laitinen, and Outi Paloposki, eds. Yhteistä kieltä tekemässä, 286-322. Helsinki: Suomalaisen Kirjallisuuden Seura.

Piippo, Irina (2012) Viewing norms dialogically. An action-oriented approach to sociolinguistic metatheory. Helsinki: Department of Modern Languages, University of Helsinki.

Rintala, Päivi (1992) Suomen kirjakielen normeista. Sananjalka 34, 47-68.

Roberts, Celia (2011) Language socialization in the Workplace. Annual Review of Applied Linguistics 30, 211-227.

Thomas, George (1991) Linguistic purism. London: Longman.

Tiililä, Ulla (2009) Tekstit viraston työssä. [Texts and text production in a city department: A study of language and context of benefit decisions] Helsinki: Suomalaisen Kirjallisuuden Seura.

Voutilainen, Eero (2016) Kielenohjailu on politiikkaa. In Irina Piippo, Johanna Vaattovaara, and Eero Voutilainen, eds. Kielen taju. Vuorovaikutus, asenteet ja ideologiat, 147-173. Helsinki: Art House.

Wenger, Etienne (1998) Communities of practice. Learning, meaning, and identity. Cambridge: Cambridge University Press. 


\section{Appendix. Transcription symbols}

$\begin{array}{ll}? & \text { rising intonation } \\ \text { falling intonation } \\ \text { ta- } & \text { level intonation } \\ @ \text { talk@ } & \text { chord cut off } \\ \text { ftalk£ } & \text { smiley in voech } \\ . \text { hh } & \text { audible inhalation } \\ (.) & \text { micropause (less than } 0.2 \text { seconds) } \\ (0.8) & \text { pause in seconds } \\ -- & \text { talk continues, data not shown } \\ \text { [talk] } & \text { word added in the translated excerpt for clarification }\end{array}$

Kokkuvõte. Jyrki Kalliokoski: "Hea halduskeel” soome keele teise keelena (S2) taustaga ametnike vaatenurgast. Seadused sätestavad Soome avaliku halduse keelekasutuse põhialustena selguse, asjakohasuse ning mõistetavuse. Artiklis võetakse vaatluse alla ametnike arvamused ja hinnangud halduskeele ideaalide kohta. Avaliku suhtluse hea keeletava küsimusi käsitletakse nende ametnike seisukohalt, kes on omandanud soome keele täiskasvanuna. Artikli keeleainestikuks on intervjuud a) soome keelt teise keelena ning b) neist kõrgemal positsioonil ja soome keelt emakeelena kõnelevate ametnikega. Artikkel käsitleb intervjueeritute arusaamu keele selguse, asjakohasuse ja mõistetavuse tähtsusest nende igapäevatöös ja keelelises sotsialiseerumises töökeskkonda, ametkondliku kommunikatsiooni kujundamisest vastuvõtja huvidega arvestades ning oma tegevusest soome halduskeele kasutajatena. Analüüsi tulemused näitavad, et mitmekeelsed ametnikud on kindlad oma keeleoskuses, teadlikud soome halduskeele eri kujudest ning piirangutest nende kasutuses. Soome keelt teise keelena kõnelevate ametnike tekstides aeg-ajalt esinevat keelelist "keerukust" selgitavad soome keelt emakeelena kõnelevad kõrgemas positsioonis olevad ametnikud bürokraatlikest žanridest tulenevate mudelitega. Formaalse standardkeele normide järgimise asemel soosivad küsitletud soome keelt emakeelena kõnelevad ametnikud hea halduskeele omadusena tõhusust.

Märksõnad: halduskeel, keeleideoloogiad, teise keele kasutus, keeleline sotsialiseerumine, keelekorraldus 